\title{
Pengembangan Kartu Peminjaman Alat Bengkel Berbasis Aplikasi Personal Computer pada Bengkel Praktikum Program Keahlian Teknik Pengelasan di SMK Negeri 1 Singosari
}

\author{
Awang Bagus Dewangga1, Imam Sudjono2, Agus Suyetno3 \\ ${ }^{1,2,3}$ Program Studi Pendidikan Teknik Mesin Jurusan Teknik Mesin \\ ${ }^{1,2,3}$ Fakultas Teknik Universitas Negeri Malang \\ ${ }^{1,2,3}$ Jalan Semarang No. 5, Malang 65145 \\ E-mail: abdewangga27@gmail.com ${ }^{1}$
}

\begin{abstract}
Abstrak: Sekolah menengah kejuruan memiliki standar kompentesi lulusan agar penyelengara pendidikan melakukan kegiatan dengan baik sesuai aturan yang ada. Salah satu yang harus dipenuhi suatu bengkel untuk memenuhi standar sarana dan prasarana adalah bengkel harus memiliki kartu peminjaman alat bengkel. Dengan adanya kartu peminjaman alat bengkel ini pengelolaan manajemen bengkel akan dipermudah dari sisi pemantauan kondisi alat bengkel yang dipakai siswa. Tujuan dari penelitian dan pengembangan ini adalah membuat kartu peminjaman alat bengkel berbasis aplikasi personal computer, supaya mempermudah siswa dan laboran dalam proses peminajaman dan monitoring alat bengkel saat praktikum. Berdasarkan validasi ahli materi, uji coba kelompok kecil dan uji coba lapangan, maka didapatkan hasil kelayakan sebesar 88,3\% dari ahli materi, $89,8 \%$ dari uji coba kelompok kecil, dan $92 \%$ dari uji coba lapangan dan dinyatakan layak sehingga aplikasi kartu peminjaman berbasis personal computer ini layak digunakan dengan revisi mempertimbangkan poin - poin yang kurang bagus.
\end{abstract}

Kata kunci: alat bengkel,aplikasi, personal computer

\begin{abstract}
Vocational high schools have a standard of graduate students so that the education is doing good activities according to the rules. One that must be fulfilled by a workshop to meet the standards of facilities and infrastructure is the workshop should have a loan card workshop tools. With the use of a loan card the workshop tools management will be made easy from the monitoring side of the condition of workshop tools used by students. The purpose of this research and development is to make workshop tools loan card based on personal computer application, so as to facilitate students and Laboran in the process and monitoring of workshop tools during practicum. Based on material expert validation, small group trials and field trials, the results of validity is $88.3 \%$ of material experts, $89.8 \%$ of small group trials, and $92 \%$ of field trials and declared valid so that the workshop tools loan card based on personal computer application deserves use with revisions considering less than good points.
\end{abstract}

Keyword: workshop tools, application, personal computer

Sekolah menengah kejuruan (SMK) merupakan salah satu dari penyelenggara pendidikan formal menengah yang secara khusus mempersiapkan peserta didiknya untuk siap bekerja di dunia industri, berwirausaha secara mandiri atau melanjutkan pendidikan yang lebih tinggi sesuai kejuruannya. Menurut UU Sidiknas pasal 15 Depdiknas tahun 2004 disebutkan bahwa pendidikan kejuruan merupakan pendidikan menengah yang mempersiapkan peserta didik terutama untuk bekerja dalam bidang tertentu. Penyelenggara sekolah menengah kejuruan didasarkan atas ketentuan yang ada pada Undang-Undang Republik Indonesia No.2 Tahun 1989 tentang sistem pendidikan Nasional Bab IV pasal 11 ayat (1) dan (3) yang berbunyi sebagai berikut: Jenis pendidikan umum, pendidikan kejuruan, pendidikan luar biasa, pendidikan kedinasan, pendidikan keagamaan, pendidikan akademik, dan pendidikan professional.

Sekolah menengah kejuruan berdasarkan tingkatan pendidikan setara dengan sekolah menengah atas, akan tetapi keduanya mempunyai tujuan yang berbeda. Pengertian mengenai sekolah kejuruan terdapat pada Peraturan Pemerintah No. 74 tahun 2008 pasal 1 ayat 21 yang menyatakan bahwa Sekolah Menengah Kejuruan yang selanjutnya disingkat SMK adalah salah satu bentuk satuan pendidikan kejuruan pada jenjang Pendidikan Menengah sebagai lanjutan dari SMP, MTs, atau bentuk lain yang sederajat atau lanjutan dari hasil belajar yang diakui sama atau setara SMP atau MTs. Sekolah menengah kejuruan melakukan proses belajar mengajar baik teori maupun praktik yang berlangsung di sekolah maupun di industri yang diharapkan dapat menghasilkan lulusan yang berkualitas. Sekolah menengah kejuruan mengutamakan pada penyiapan siswa untuk berlomba memasuki lapangan kerja. Pendidikan di sekolah Menengah Kejuruan (SMK) bertujuan meningkatkan pengetahuan dan keterampilan dan siswa untuk menyiapkan mereka sebagai tenaga kerja tingkat menengah yang terampil, terdidik dan professional serta mampu mengembangkan diri sejalan dengan perkembangan ilmu pengetahuan dan teknologi. 
Finch \& Crunkilton (1979) membagi tujuan pendidikan ke dalam dua kategori, yakni: "education for life and education for earning a living". Berdasarkan klasifikasi tersebut secara umum pendidikan dapat dibagi dua, yaitu: pendidikan umum atau pendidikan hidup (education for life), dan pendidikan kejuruan atau pendidikan untuk mencari penghasilan guna kebutuhan kehidupan (education for earning a living).

Pendidikan kejuruan diartikannya sebagai pendidikan untuk mencari penghasilan bagi kehidupan atau pendidikan untuk bekerja (education for work). Kongres Amerika Serikat mendefinisikan pendidikan kejuruan (vocational education) sebagai: Organized educational programs which are directly related to the preparation of individuals for paid or unpaid employment, or for additional preparation for a career requiring other than a baccalaureate or advance degree (Calhoun \& Finch, 1982). Definisi tersebut memberi petunjuk bahwa pendidikan kejuruan mengandung makna sebagai persiapan untuk bekerja, serta pelatihan tambahan yang dibutuhkan oleh kariernya. Dengan kata lain pendidikan kejuruan berfungsi pada dua keperluan, yakni; pertama, sebagai persiapan untuk keperluan bekerja, dan kedua, untuk peningkatan dalam karier.

Tolok ukur dunia pendidikan menengah di Indonesia mengacu pada 8 (delapan) Standar Nasional Pendidikan yang dikembangakan oleh Badan Standar Nasional Pendidikan (BSNP), yaitu pemberlakuannya disahkan oleh Depdiknas RI melalui Undang-Undang Nomor 20 Tahun 2003. Standar Nasional Pendidikan mempunyai kriteria minimum yang semestinya dipenuhi oleh penyelenggara pendidikan. Standar tersebut meliputi : (1) Standar kompetensi lulusan; (2) Standar isi; (3) Standar proses; (4) Standar pendidikan dan tenaga kependidikan; (5) Standar sarana dan prasarana; (6) Standar pengelolaan; (7) Standar pembiayaan pendidikan; dan (8) Standar penilaian pendidikan.

Sekolah menengah kejuruan memiliki standar kompentesi lulusan agar penyelengara pendidikan melakukan kegiatan dengan baik sesuai aturan yang ada. Menguasai kompentensi program keahlian dan kewirausahaan baik untuk memenuhi tuntutan dunia kerja maupun untuk mengikuti pendidikan tinggi sesuai dengan kejuruannya yaitu Peraturan Menteri Pendidikan Nasional Nomor 40 tahun 2008 tentang standar sarana dan prasarana. Bengkel merupakan fasilitas yang sangat penting di SMK kelompok teknologi dan rekayasa program studi keahlian teknik pengelasan. Bengkel ini harus diupayakan memenuhi standar sarana dan prasarana agar tujuan SMK tercapai. Salah satu yang harus dipenuhi suatu bengkel untuk memenuhi standar sarana dan prasarana adalah bengkel harus memiliki kartu peminjaman alat bengkel. Kartu ini berfungsi untuk merekam distribusi peminjaman alat -alat bengkel yang digunakan untuk praktikum siswa di bengkel tersebut. Dengan adanya kartu peminjaman alat bengkel ini pengelolaan manajemen bengkel akan dipermudah dari sisi pemantauan kondisi alat bengkel yang dipakai siswa.

Dari observasi penulis yang dilakukan di SMK Negeri 1 Singosari di dapati kartu peminjaman alat bengkel yang berada di SMK Negeri 1 Singosari berbentuk print out dan di isi secara manual, sehingga menurut pandangan penulis akan lebih efektif jika kartu peminjaman alat bengkel di kemas secara rapi dalam bentuk aplikasi yang dapat dioperasikan melalui personal computer ataupun di android. Pencatatan peminjaman aset secara manual dengan menggunakan buku pencatatan peminjaman barang atau mengisi form peminjaman barang yang kemudian dipindahkan ke program Microsoft Excel akan timbul masalah yaitu efisiensi proses peminjaman dan lamanya proses pelaporan data (Yusuf; 2017). Menurut Rajendra, dkk. (2012) Pemrosesan basis data menjadi sebuah aplikasi atau perangkat tidak hanya mempercepat dalam memperoleh informasi, tetapi juga meningkatkan pelayanan sehingga efektivitas proses kerja dapat dimaksimalkan. Selain itu penulis juga melaksanakan analisis kebutuhan kepada siswa yang sedang melaksanakan praktikum di bengkel Teknik Pengelasan SMK N 1 Singosari yang berjumlah 29 siswa dengan hasil 86,2\% siswa membutuhkan aplikasi Kartu Peminjaman.

\section{METODE}

Model yang digunakan dalam penelitian dan pengembangan ini adalah model Research and Development. Menurut Sukmadinata (2016) Penelitian dan Pengembangan atau Research and Development (R \& D) adalah suatu proses atau langkahlangkah untuk mengembangkan suatu produk baru, atau menyempurnakan prosuk yang telah ada yang dapat dipertanggungjawabkan, langkah-langkah penelitian dan pengembangan yang digunakan adalah berdasarkan model ADDIE, yaitu Analysis (Analisis), Design (Desain), Development (Pengembangan), Implementation (Implementasi), dan Evaluation (Evaluasi). Alur penelitian ADDIE dapat dilihat pada gambar 1.

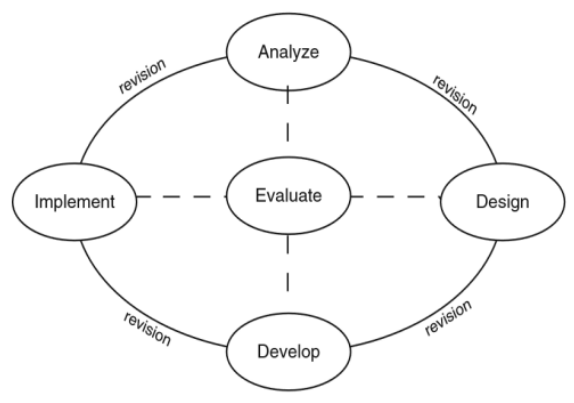

Gambar 1. Alur penelitian ADDIE 
Tahap pertama yang ada dalam pengembangan model ADDIE adalah tahap Analisis. Tahap analisis merupakan suatu proses analisa kebutuhan, mengidentifikasi masalah atau kebutuhan dan melakukan analisis tugas. Out put yang dihasilkan berupa karakteristik atau profile dari program. Selanjutnya yang kedua adalah tahap Desain, Tahap ini dikenal dengan istilah membuat rancangan, misal sebuah gedung sebelum didirikan harus ada rancang bangun berupa sketsa ataupun lain sebagainya. Setelah melalui tahap kedua kemudian lanjut pada tahap yang ketiga, tahap ketiga ini adalah tahap Pengembangan. Pengembangan merupakan proses mewujudkan desain yang sudah dirancang menjadi real. Dalam artian pada tahap ini segala sesuatu yang dibutuhkan atau segala sesuatu pendukung proses penyusunan produk harus disiapkan secara keseluruhan. Kemudian lanjut ke tahap 4, tahap 4 ini adalah tahap Implementasi. Implementasi atau penerapan merupakan tahap untuk menerapkan sistem ataupun program yang dikembangkan. Pada tahap ini semua yang telah dikembangkan diatur sedimikian rupa sesuai dengan desain awal dengan masing-masing peran dan fungsinya. Setelah produk yang dikembangkan siap, maka siap dilakukan uji coba melalui kelompok kecil. Tahap yang terakhir adalah tahap evaluasi. Evaluasi merupakan proses untuk menentukan apakah produk yang sudah tercipta memenuhi persyaratan kelayakan untuk dioperasikan. Pada dasarnya evaluasi ini bersifat formatif yang nantinya akan digunakan untuk revisi atau perbaikan untuk mewujudkan produk yang lebih sempurna

Desain uji coba secara keseluruhan dilakukan dalam 3 tahap, yaitu uji ahli (software dan isi program), kemudian dilanjutkan dengan uji coba kelompok kecil, dan uji coba lapangan. Tahap validasi ahli bertujuan untuk mendapatkan penilaian, komentar, dan saran dari ahli media materi terhadap kelayakan kartu peminjaman alat bengkel berbasis aplikasi Personal Computer yang akan dihasilkan. Menurut Suparman (1997) jumlah yang diperlukan untuk uji coba kelompok kecil han ya 8-20 responden. Menurut Morrison, Ross \& Kemp (2001) tujuan dari uji coba ini adalah mengidentifikasi kelebihan dan kekurangan dari desain yang sedang dikembangkan untuk memperoleh perbaikan sebelum dilanjut pada tahap final. Selanjutnya setelah dilaksanakan uji coba kelompok kecil, jika ditemukan kekurangan maka akan dilaksanakan revisi atau perbaikan sesuai data yang didapat dari responden secara maksimal. Tahap uji coba lapangan merupakan tahap uji coba terakhir setelah melawati tahap validasi ahli materi dan tahap uji coba kelompok kecil. Perbedaan mendasar dari uji coba lapangan ini dengan uji coba sebelumnya adalah produk, lingkungan pelaksanaan, dan pelaksanaan uji coba (Suparman; 1997). Jumlah responden yang digunakan dalam uji coba ini lebih besar daripada uji coba kelompok kecil. Menurut Suparman (1997) jumlah responden yang digunakan dalam uji coba lapangan adalah 15-30 responden.

Subjek penelitian dalam penelitian dan pengembangan ini adalah kepala bengkel dan siswa pada program keahlian Teknik Pengelasan di SMK Negeri 1 Singosari. Objek penelitian pada penelitian dan pengembangan ini adalah kartu peminjaman alat bengkel berbasis aplikasi Personal Computer pada bengkel praktikum program keahlian Teknik Pengelasan di SMK Negeri 1 Singosari.

Jenis data uji coba produk yang digunakan dalam penelitian dan pengembangan kartu peminjaman alat bengkel berbasis aplikasi Personal Computer pada program keahlian Teknik Pengelasan di SMK Negeri 1 Singosari ini yaitu data kuantitatif. Data kuantitatif diperoleh dari penyebaran angket kepada penguji uji validasi ahli, responden uji coba kelompok kecil, dan responden uji coba lapangan. Data tersebut kemudian akan diolah dan dijadikan dasar penilaian kelayakan produk aplikasi yang dikembangkan.

Instrumen pengumpulan data yang digunakan dalam penelitian dan pengembangan kartu peminjaman alat bengkel berbasis aplikasi Personal Computer pada bengkel praktikum program keahlian Teknik Pengelasan di SMK Negeri 1 Singosari ini menggunakan angket. Tujuan penggunaan angket ini adalah untuk memperoleh data kuantitatif demi kesempurnaan dan kelayakan program aplikasi yang dihasilkan. Pengumpulan data dilakukan pada tahap uji coba produk. Jenis angket yang digunakan dalam penelitian ini yaitu angket semi tertutup dengan menggunakan skala likert.

Metode analisa data penelitian menggunakan metode deskriptif. Analisis deskriptif adalah analisis yang digunakan untuk menguji variabel yang bersifat kuantitatif. Metode deskriptif adalah suatu metode dalam meneliti status sekelompok manusia, suatu objek, suatu konteks, suatu sistem pemikiran, ataupun suatu kelas peristiwa pada masa sekarang. Tujuan dari penelitian deskriptif ini adalah untuk membuat deskripsi, menggambarkan atau melukiskan secara sitematis, faktual, dan akurat mengenai fakta-fakta, sifat-sifat serta hubungan antar fenomena yang diselidiki. Menurut Hartono (2013) Analisis deskriptif dilakukan guna mengetahui gambaran data yang akan dianalisis. Membaca tabel dan diagram merupakan bagian dari kegiatan analisis deskriptif. Analisis bukan hanya sekedar membaca tabel dan diagram, melainkan mampu membaca dibalik angkaangka, simbol, dan gambar. Teknik pengolahan data menggunakan pengukuran dengan skala likert. Menurut Sugiyono (2010), menjelaskan bahwa skala likert digunakan untuk mengukur sikap, pendapat, dan persepsi seseorang atau kelompok orang tentang sebuah fenomena sosial. Skala likert dapat memberikan alternatif jawaban dari sosial instrumen dengan gradasi dari sangat positif hingga sangat negatif. Pertimbangan pemilihan pengukuran ini karena memudahkan responden untuk memilih jawaban. Kriteria jawaban yang dibagikan kepada responden menggunakan kuisinoer/angket berupa pengukuran skala likert, responden diminta menggunakan program aplikasi secara keseluruhan dengan berhadapan secara langsung. Responden diminta memberikan salah satu pilihan dari jawaban yang telah disediakan. 


\section{HASIL DAN PEMBAHASAN}

Hasil pengembangan adalah pembahasan hasil dari penelitian yang sudah dilaksanakan oleh pengembang berdasarkan data dan fakta yang sudah diperoleh. Pada bab ini berisi tentang hasil analisis kebutuhan, hasil desain, hasil pengembangan, hasil validasi ahli, hasil implementasi dan revisi

\section{Hasil Analisis Kebutuhan}

Analisis kebutuhan dilaksanakan dengan tujuan untuk mengetahui apakah diperlukan pengembangan pada kartu peminjaman alat bengkel pada bengkel praktikum program keahlian Teknik Pengelasan di SMK Negeri 1 Singosari untuk menunjang efektivitas proses praktikum demi mencapai tujuan pembelajaran. Pada analisis kebutuhan yang dilaksanakan pengembang terdapat 10 item pertanyaan yang diberikan kepada 29 responden, dimana responden merupakan siswa kelas XI program keahlian Teknik Pengelasaan SMK Negeri 1 Singosari yang sedang melaksanakan praktikum. Hasil dari analisis kebutuhan tersebut disajikan sebagai berikut: 1) Pada poin pertama item yang ditanyakan oleh pengembang adalah tentang pengaruh pelaksanaan praktikum terhadap keterampilan siswa. Semua responden memberi jawaban YA (100\%). Dari hasil tersebut menunjukkan pelaksanaan praktikum mempengaruhi keterampilan siswa. 2) Pada poin ke-2 item yang ditanyakan oleh pengembang adalah tentang kelengkapan alat untuk menyelesaikan pekerjaan saat pelaksanaan praktikum. 27 responden memilih jawaban YA $(93,1 \%)$ sisanya 2 responden menjawab TIDAK $(6,9 \%)$. Dari hasil tersebut menunjukkan kelengkapan alat sudah dapat menyelesaikan semua pekerjaan saat praktikum. 3) Pada poin ke-3 yang ditanyakan oleh pengembang adalah tentang bagusnya kualitas pelaksanaan peminjaman alat bengkel. 24 reponden memilih jawaban YA (82,7\%) sisanya 5 responden memilih jawaban TIDAK (17,3\%). Dari hasil tersebut menunjukkan pelaksanaan peminjaman alat termasuk dalam kategori bagus. 4) Pada poin ke-4 pengembang menanyakan tentang bantuan guru atau laboran pada saat proses peminjaman alat bengkel. 21 responden memilih jawaban YA $(72,4 \%)$ dan sisanya 8 responden memilih jawaban TIDAK (27,6\%). Dari hasil tersebut menunjukkan guru cukup membantu dalam proses peminjaman. 5) Pada poin ke-5 yang ditanyakan oleh pengembang adalah tentang pemeriksaan kondisi alat sebelum dan sesudah dipinjam oleh siswa. 22 responden memilih jawaban YA $(75,8 \%)$ dan sisanya 7 responden memilih jawaban TIDAK $(24,2 \%)$. Hasil tersebut menunjukkan pemeriksaan alat tidak selalu dilakukan. 6) Pada poin ke-6 pengembang menanyakan tentang penggunaan kartu peminjaman saat pelaksanaan praktikum. 2 responden memilih jawaban YA (6,9\%) dan sisanya 27 responden memilih jawaban TIDAK $(93,1 \%)$. Dari hasil tersebut saat pelaksanaan praktikum sangat sering tidak menggunakan kartu peminjaman. 7) Pada poin ke-7 yang ditanyakan oleh pengembang adalah tentang efektivitas kartu peminjaman manual. 9 responden memilih jawaban YA $(31,03 \%)$ dan sisanya 20 responden memilih jawaban TIDAK $(68,97 \%)$. Dari hasil tersebut dapat disimpulkan bahwa kartu peminjaman manual tidak bekerja secara efektif. 8) Pada poin ke-8 item yang ditanyakan oleh pengembang adalah tentang tanggung jawab individu tiap siswa terhadap alat yang dipinjam. 27 responden memilih jawaban YA $(93,1 \%)$ dan sisanya 2 responden memilih jawaban TIDAK (6,9\%). Dari hasil tersebut menggambarkan bahwa tiap siswa bertanggung jawab secara individu terhadap alat yang dipinjam. 9) Pada poin ke-9 item yang ditanyakan oleh pengembang adalah kebutuhan siswa terhadap kartu peminjaman alat yang berbasis software pada PC. 25 responden memilih jawaban YA $(86,2 \%)$ dan sisanya 4 sisanya memilih jawaban TIDAK (13,8\%). Dari hasil tersebut dapat disimpulkan bahwa siswa membutuhkan kartu peminjaman alat yang berbasis software pada PC. 10) Pada poin terakhir item yang ditanyakan oleh pengembang adalah tentang efektivitas proses peminjaman alat jika menggunakan kartu peminjaman alat yang berbasis software pada PC. 27 responden memilih jawaban YA $(93,1 \%)$ dan sisanya 2 responden memilih jawaban TIDAK (6,9\%). Dari hasil tersebut menggambarkan bahwa menurut siswa proses peminjaman alat akan lebih efektif jika menggunakan kartu peminjaman alat yang berbasis software pada PC.

Berdasarkan hasil analisis kebutuhan yang sudah dilaksanakan oleh pengembang dapat diambil kesimpulan bahwa alat - alat yang terdapat di bengkel praktikum program keahlian teknik pengelasan SMK Negeri 1 Singosari sudah dapat membantu para siswa untuk meningkatkan keterampilan mereka pada bidangnya dan mampu menyelesaikan seluruh pekerjaan yang ditugaskan dalam proses praktikum. Kemudian para siswa merasa bahwa menggunakan kartu peminjaman manual kurang efektif saat pelaksanaan praktikum, para siswa beranggapan bahwa jika menggunakan software yang sedang dikembangkan oleh pengembang akan lebih efektif daripada menggunakan kartu peminjaman yang digunakan secara manual. Dengan adanya software kartu peminjaman ini pemantauan peralatan yang ada di bengkel praktikum program keahlian teknik pengelasan SMK Negeri 1 Singosari akan lebih mudah dilakukan, dan para siswa akan lebih bertanggung jawab terhadap alat yang digunakannya karena dalam proses kerja software ini siswa dituntut untuk lebih bertanggung jawab dan berhati - hati dalam menggunakan alat - alat yang dipinjam.

\section{Hasil Desain}

Berdasarkan prosedur model pengembangan ADDIE yang digunakan oleh pengembang terdapat proses desain yang bertujuan untuk menentukan rancangan awal sebuah produk yang sedang dikembangkan. Dalam pengembangan Kartu peminjaman alat bengkel berbasis aplikasi Personal Computer ini meliputi perangkat pembuat media dan strategi pengembangan. Perangkat yang digunakan dalam pembuatan media kartu peminjaman ini adalah perangkat lunak atau software Delphi. Delphi merupakan sebuah software untuk pemrograman yang diproduksi oleh Borland dimana Delphi ini begitu popular. Dikhususkan untuk bahasa pemrograman Delphi jelas berbeda dengan aplikasi windows lain seperti Ms Office 
ataupun sejenisnya. Delphi untuk bahasa pemrograman berarti Delphi merupakan software untuk membuat aplikasi melalui pemrograman atau biasa disebut coding.

Hasil dari strategi pengembangan ini berupa rancangan desain kerja (work design). Work Design adalah rancangan mekanisme yang nantinya digunakan untuk komunikasi antara pengguna dengan sistem, bentuk dari rancangan tersebut dapat dilihat pada gambar desain kerja sebagai berikut: 1) Desain kerja halaman menu utama (Home) 2) Desain kerja pada tampilan system 3) Desain kerja pada tampilan input data 4) Desain kerja pad menu transaksi 5) Desain kerja pada tampilan laporan.

\section{Hasil Pengembangan}

Setelah dilakukan beberapa proses perancangan pada tahap desain dalam pembuatan aplikasi kartu peminjaman alat bengkel yang sudah ditetapkan seperti dalam desain kerja, maka dihasilkan aplikasi kartu peminjaman aalat bengkel berbasis software personal computer yang tampilannya menarik dan sesuai dengan kebutuhan yang dibutuhkan pada bengkel praktikum program keahlian teknik pngelasan di SMK Negeri 1 Singosari. Dalam tampilan aplikasi kartu peminjaman berbasis personal computer ini terdiri dari menu, dimana didalam menu terdapat opsi - opsi yang dapat dipilih sesuai dengan kebutuhan pengoperasian aplikasi tersebut. Pada pengembangan ini software yang digunakan untuk mengembangkan aplikasi kartu peminjaman berbasis personal computer adalah software besutan Borland Delphi yaitu Delphi7.

Hasil dari realisasi desain yang sudah dikembangkan adalah sebagai berikut 1) Tampilan shortcut di Desktop merupakan tampilan pintasan aplikasi kartu peminjaman yang digunakan untuk akses masuk kedalam aplikasi dengan cara klik 2 kali pada shortcut di Desktop tersebut. Berikut merupakan tampilan Shortcut aplikasi kartu peminjaman berbasis aplikasi personal computer di Desktop 2) Tampilan menu utama merupakan tampilan yang disajikan pada saat awal masuk ke aplikasi kartu peminjaman berbasis personal computer. Pada tampilan menu utama terdapat 4 menu yang didalamnya memiliki opsi opsi yang memiliki fungsi masing - masing sesuai dengan kebutuhan. Menu - menu yang terdapat pada menu utama adalah menu system, menu input data, menu transaksi, dan yang terakhir menu laporan. 3) Menu system merupakan salah satu menu yang terdapat pada menu utama. Pada menu system terdapat 2 opsi didalamnya yang memiliki fungsi masing - masing. 2 opsi yang terdapat pada menu system adalah opsi database dan opsi keluar. Pada opsi database digunakan saat akan mengatur database, dimana database merupakan inti dari pengoperasian aplikasi kartu peminjaman ini. Selanjutnya pada opsi keluar digunakan jika akan keluar dari aplikasi menuju ke Desktop kembali. 4) Pada tampilan input data terdapat beberapa opsi di dalamnya yaitu, input kelas, input kondisi barang, input barang, dan input tambah stok barang. Fungsi dari input data ini adalah untuk menambah atau memperbarui informasi yang nantinya digunakan untuk pengisian form peminjaman dan pengembalian saat pengoperasian aplikasi kartu peminjaman. 5) Pada menu transaksi terdapat 2 opsi yaitu, opsi peminjaman barang dan opsi pengembalian barang. Fungsi dari masing - masing opsi sesuai dengan namanya, opsi peminjaman barang digunakan untuk peminjaman dan opsi pengembalian digunakan untuk pengembalian barang. 6) Pada menu laporan terdapat 2 opsi di dalamnya yaitu, opsi laporan transaksi peminjaman dan opsi laporan stok barang. Pada opsi laporan transaksi terdapat rekapitulasi semua barang yang dipinjam termasuk barang yang belum kembali maupun barang yang sudah kembali. Hasil rekapitulasi berupa file dengan format .qrt yang dapat di eksport ke dalam file dengan format .pdf. pada opsi laporan stok barang terdapat rekapitulasi jumlah stok barang yang dimiliki sekolah seluruhnya dengan jumlah stok barang yang dipinjam dan belum dikembalikan.

\section{Hasil Validasi Ahli Materi}

Validasi ahli materi dilaksanakan pada hari Senin tanggal 2 September 2019 oleh Hendra Ristananda, S.Pd. yang merupakan guru sekaligus kepala bengkel program keahlian teknik pengelasan di SMK Negeri 1 Singosari. Variable yang menjadi aspek pengamatan tentang kualitas materi aplikasi kartu peminjaman berbasis personal computer disajikan sebagai berikut:

Tabel 1. Hasil Validasi Ahli Materi

\begin{tabular}{cccccc}
\hline No & Skor & No & Skor & No & Skor \\
\hline $\mathbf{1 .}$ & 3 & $\mathbf{6 .}$ & 4 & $\mathbf{1 1 .}$ & 4 \\
\hline $\mathbf{2 .}$ & 2 & $\mathbf{7 .}$ & 4 & $\mathbf{1 2 .}$ & 3 \\
\hline 3. & 2 & $\mathbf{8 .}$ & 4 & $\mathbf{1 3 .}$ & 4 \\
\hline $\mathbf{4 .}$ & 4 & $\mathbf{9 .}$ & 4 & $\mathbf{1 4 .}$ & 4 \\
\hline $\mathbf{5 .}$ & 3 & $\mathbf{1 0 .}$ & 4 & $\mathbf{1 5 .}$ & 4 \\
\hline
\end{tabular}

Berdasarkan tabel 1 dan mengacu pada tabel kriteria analisis presentase kelayakan, didpatkan kesimpulan bahwa total skor dari seluruh aspek yang diperoleh dari validasi ahli materi yaitu 53 dari total nilai 60. Jumlah presentase jawaban validator adalah $88,3 \%$, dan dinyatakan layak pada keterangan kriteria validasi namun perlu dilakukan sesuai saran dari ahli materi dengan memperhatikan aspek - aspek yang dinilai kurang layak.

\section{Uji Coba Kelompok Kecil}

Uji coba kelompok kecil dilaksanakan pada hari Senin tanggal 16 September 2019, dimana responden uji coba kelompok kecil ini adalah 9 siswa kelas XI yang melaksanakan praktikum di program keahlian teknik pengelasan SMK Negeri 
166 JURNAL TEKNIK MESIN DAN PEMBELAJARAN, Volume 2, Nomor 2, Desember 2019, Halaman: $161-168$

1 Singosari. Variabel yang menjadi aspek penilaian tentang kelayakan aplikasi kartu peminjaman berbasis personal computer disajikan sebagai berikut:

Tabel 2. Hasil Uji Coba Kelompok Kecil

\begin{tabular}{lccccc}
\hline No & Skor & No & Skor & No & Skor \\
\hline $\mathbf{1 .}$ & 35 & $\mathbf{7 .}$ & 35 & $\mathbf{1 3 .}$ & 36 \\
\hline $\mathbf{2 .}$ & 36 & $\mathbf{8 .}$ & 34 & $\mathbf{1 4 .}$ & 36 \\
\hline 3. & 35 & $\mathbf{9 .}$ & 36 & $\mathbf{1 5 .}$ & 36 \\
\hline $\mathbf{4 .}$ & 32 & $\mathbf{1 0 .}$ & 36 & $\mathbf{1 6 .}$ & 36 \\
\hline $\mathbf{5 .}$ & 33 & $\mathbf{1 1 .}$ & 36 & $\mathbf{1 7 .}$ & 36 \\
\hline $\mathbf{6 .}$ & 32 & $\mathbf{1 2 .}$ & 36 & $\mathbf{1 8 .}$ & 36 \\
\hline
\end{tabular}

Berdasarkan tabel 2 dan mengacu pada tabel kriteria analisis persentase kelayakan, hasil uji coba kelompok kecil dapat dianalisis sebagai berikut; total skor dari seluruh aspek yang diperoleh dari uji coba kelompok kecil adalah 582 dari skor maksimum 648. Jumlah keseluruhan jawaban responden mencapai tingkat 89,8\% dan dinyatakan layak sehingga aplikasi kartu peminjaman berbasis personal computer ini layak digunakan.

\section{Uji Coba Lapangan}

Uji coba lapangan dilaksanakan pada hari Rabu tanggal 18 September 2019, dimana responden uji coba kelompok kecil ini adalah 25 siswa kelas XI yang melaksanakan praktikum di program keahlian teknik pengelasan SMK Negeri 1 Singosari. Variabel yang menjadi aspek penilaian tentang kelayakan aplikasi kartu peminjaman berbasis personal computer disajikan sebagai berikut:

Tabel 3. Hasil Uji Coba Lapangan

\begin{tabular}{cccccc}
\hline No & Skor & No & Skor & No & Skor \\
\hline 1. & 100 & $\mathbf{7 .}$ & 93 & $\mathbf{1 3 .}$ & 91 \\
\hline $\mathbf{2 .}$ & 100 & $\mathbf{8 .}$ & 91 & $\mathbf{1 4 .}$ & 90 \\
\hline 3. & 100 & $\mathbf{9 .}$ & 97 & $\mathbf{1 5 .}$ & 90 \\
\hline $\mathbf{4 .}$ & 88 & $\mathbf{1 0 .}$ & 95 & $\mathbf{1 6 .}$ & 90 \\
\hline $\mathbf{5 .}$ & 93 & $\mathbf{1 1 .}$ & 96 & $\mathbf{1 7 .}$ & 90 \\
\hline $\mathbf{6 .}$ & 87 & $\mathbf{1 2 .}$ & 92 & $\mathbf{1 8 .}$ & 73 \\
\hline
\end{tabular}

Berdasarkan tabel 3 dan mengacu pada tabel kriteria tingkat validitas atau kelayakan, hasil uji coba lapangan dapat dianalisis sebagai berikut; total skor dari seluruh aspek yang diperoleh dari uji coba lapangan adalah 1656 dari skor maksimum 1800. Jumlah keseluruhan jawaban responden mencapai tingkat $92 \%$ dan dinyatakan layak sehingga aplikasi kartu peminjaman berbasis personal computer ini layak digunakan dengan revisi mempertimbangkan poin - poin yang kurang layak.

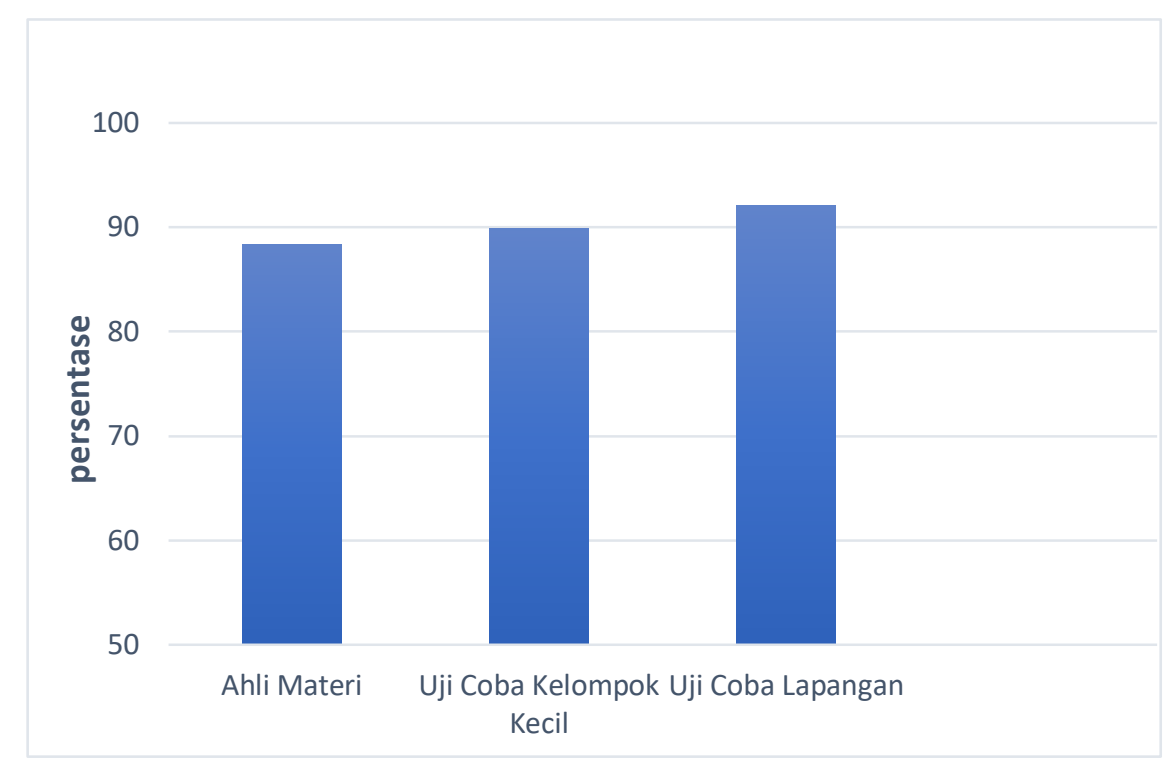

Gambar 2. Hasil Uji Kelaakan Aplikasi 
Berdasarkan validasi ahli materi, uji coba kelompok kecil dan uji coba lapangan, maka didapatkan hasil kelayakan sebesar 88,3\% dari ahli materi, 89,8\% dari uji coba kelompok kecil, dan 92\% dari uji coba lapangan. Hasil rata - rata yang diperoleh disajikan pada Gambar 2 diatas.

\section{Revisi}

Berdasarkan hasil analisis data, saran validator ahli materi, dan saran responden maka pengembang menindak lanjuti dengan melaksanakan revisi dengan tujuan memperbaiki kekurangan aplikasi kartu peminjaman berbasis personal computer supaya kedepannya dapat berfungsi dengan baik dan sesuai dengan kebutuhan. Berikut merupakan beberapa saran yang diberikan oleh validator ahli materi dan responden uji coba kelompok kecil serta uji coba lapangan.

Tabel 4. Saran dan Revisi Produk

\begin{tabular}{lll}
\hline No & Saran Perbaikan & Tindak Lanjut \\
\hline 1. & $\begin{array}{l}\text { Tata letak tabel dan tombol diperbaiki lagi supaya lebih } \\
\text { rapi dan efisien }\end{array}$ & $\begin{array}{l}\text { Melakukan perbaikan terhadap tata letak tabel dan tombol } \\
\text { sesuai arahan dari validator }\end{array}$ \\
\hline 2. & Ukuran huruf pada tabel lebih diperbesar & $\begin{array}{l}\text { Penambahan ketebalan dan memperbesar ukuran huruf } \\
\text { pada tabel - tabel }\end{array}$ \\
\hline 3. & $\begin{array}{l}\text { Input data barang dan } \text { update data barang lebih baik } \\
\text { dilakukan pada database }\end{array}$ & $\begin{array}{l}\text { Mengubah logika pada coding sehingga Input data barang } \\
\text { dan update data barang hanya dapat dilakukan pada } \\
\text { database }\end{array}$ \\
\hline 4. & Pemilihan warna kurang bagus & $\begin{array}{l}\text { Mengubah warna - warna yang kurang sesuai dengan } \\
\text { warna yang lebih halus dan lembut }\end{array}$ \\
\hline 5. & Banyak ukuran huruf yang kurang besar dan tebal & $\begin{array}{l}\text { Penambahan ketebalan dan memperbesar ukuran huruf } \\
\text { pada aplikasi }\end{array}$ \\
\hline 6. & Latar belakang lebih bagus jika tanpa gambar & $\begin{array}{l}\text { Menghapus gambar pada latar belakang aplikasi dan } \\
\text { mengganti dengan warna yang lembut }\end{array}$ \\
\hline
\end{tabular}

Produk akhir dari pengembangan kartu peminjaman alat bengkel berupa software berbasis personal computer dengan format berupa .exe yang dapat di install dan selanjutnya dijalankan disemua merk personal computer. Aplikasi kartu peminjaman ini bisa dikatakan sebagai produk jadi karena sudah melewati tahap revisi yang mengacu pada saran ahli materi dan responden yang diperoleh saat validasi, uji coba kelompok kecil dan uji coba lapangan.

\section{PENUTUP DAN SARAN}

\section{Simpulan}

Hasil dari produk pengembangan kartu peminjaman alat bengkel berbasis aplikasi personal computer ini digunakan di bengkel praktikum program keahlian teknik pengelasan SMK Negeri 1 Singosari sebagai pengganti kartu peminjaman alat bengkel manual yang digunakan sebelumnya, berdasarkan analisis yang dilakukan pengembang sebelumnya kartu peminjaman alat bengkel berbasis aplikasi personal computer ini akan lebih efektif digunakan karena tidak membutuhkan waktu yang lama saat pengisian form peminjaman dan pengembalian, selain itu kartu peminjaman manual dirasa kurang efektif karena bisa saja jika tidak baik dalam penyimpanan maka berkas akan hilang dan sulit dilakukan penelusuran alat yang dipinjam serta sulitnya monitoring ketersediaan alat yang ada di bengkel tersebut. Dengan menggunakan kartu peminjaman alat bengkel berbasis aplikasi personal computer ini rekap peminjaman dan pengembalian akan dapat disimpan dalam bentuk soft file yang memiliki kecil kemungkinan akan hilang kecuali terhapus dan proses monitoring ketersediaan alat yang ada di bengkel akan lebih mudah dilaksanakan karena pada kartu peminjaman alat bengkel berbasis aplikasi personal computer ini akan otomatis update saat ada kegiatan peminjaman dan pengembalian. Dengan demikian diharapkan dengan adanya kartu peminjaman alat bengkel berbasis aplikasi personal computer ini proses pembelajaran praktikum pada program keahlian teknik pengelasan di SMK Negeri 1 Singosari akan lebih berkualitas dan keterampilan para siswa akan meningkat dengan baik serta kepala bengkel akan lebih mudah melakukan monitoring ketersediaan alat yang terdapat di bengkel tersebut.

\section{Saran}

Berikut ini adalah beberapa saran yang dapat digunakan untuk mengoptimalkan pemanfaatan kartu peminjaman berbasis aplikasi personal computer ini: (1) kartu peminjaman ini dapat digunakan secara umum, tidak hanya pada program keahlian teknik pengelasan namun juga pada seluruh program keahlian di SMK Negeri 1 Singosari; (2) Menggunakan personal computer 32 bit atau 64 bit dengan spesifikasi sistem operasi diatas windows 7 supaya aplikasi dapat dioperasikan dengan maksimal; (3) Rekapitulasi hasil transaksi peminjaman dan pengembalian dapat digunakan untuk kegiatan - kegiatan yang membutuhkan laporan intensitas penggunaan alat bengkel; (4) Pengembangan lebih lanjut terhadap produk selanjutnya diharapkan tidak hanya digoperasikan secara offline namun bisa dikembangkan dengan sistem online dengan memperhatikan ketersediaan jaringan internet pada tempat penggunaan produk; (5) Pada hasil laporan transaksi peminjaman dan pengembalian perlu ditambah dengan format file .pdf supaya pengguna tidak perlu melakukan ekspor file dari .qrt ke .pdf, dengan demikian proses penyimpanan file akan lebih efektif dilakukan; (6) Mempromosikan aplikasi kepada seluruh program keahlian yang ada 
pada SMK Negeri 1 Singosari dengan tujuan supaya semua program keahlian mendapat kemudahan dalam pengelolaan alat bengkel seperti program keahlian Teknik Pengelasan.

\section{DAFTAR RUJUKAN}

Branch, R.M. 2009. Instructional Desig: The ADDIE Approach. New York: Springer.

C.C, Calhoun \& A.V, Finch. 1982. Vocational Education : Concept and Operations. Belmount California : Wads Worth Publishing Company.

Curtis R, Finch \& John R, Crunkilton. 1979. Curriculum development in vocational and technical education : planning, content, and implementation. Boston: Allyn and Bacon.

Hartono, Bambang. 2013. Sistem Informasi Manajemen Berbasis Komputer. Jakarta: Rineka Cipta.

Kemdikbud. 2008. Peraturan Pemerintah RI Nomor 40, Tahun 2008, tentang Standar Sarana dan Prasarana untuk Sekolah Menengah Kejuruan/Madrasah Aliyah Kejuruan (SMK/SMA).

Morrison, G.R., Ross, S.M., \& Kemp, J.E. 2001. Designing Effective Instruction (Third Edition). New York: JOHN \& SONS, INC.

Peraturan Pemerintah Republik Indonesia No. $74 \quad$ Tahun 2008 Pasal 1 ayat $21 . \quad$ (Online), (https://bengkulu.kemenag.go.id/file/file/Sirandang/PP74.pdf), diakses 19 Maret 2019.

Rajendra, R. Dkk. 2012. Sistem Inventory dan Peminjaman Barang Pada Laboratorium Program Studi Sistem Komputer. (Online), (https://jtsiskom.undip.ac.id/index.php/jtsiskom/article/view/4736).

Sugiyono. 2010. Statistika Untuk Penelitian. Bandung: Alfabeta.

Sugiyono. 2011. Metode Penelitian Pendidikan Kuantitatif, Kualitatif, dan R\&D. Bandung: Alfabeta.

Sukmadinata. 2012. Metode Penelitian Pendidikan. Bandung: PT. Remaja Rodakarya.

Suparman, A. 1997. Desain Instruksional. Jakarta: PAU-PPAI Direktorat Jendral PendidikanTinggi Departemen Pendidikan dan Kebudayaan.

Undang-Undang Republik Indonesia No. 2 Tahun 1989 tentang Sistem Pendidikan Nasional. (Online), (https://jdih.kemenkeu.go.id/fulltext/1989/2TAHUN 1989UU.HTM), diakses 19 Maret 2019.

Undang-Undang Republik Indonesia No 20 Tahun 2003 tentang Sistem Pendidikan Nasional. (Online), (https://kelembagaan.ristekdikti.go.id/wp-content/uploads/2016/08/UU_no_20_th_2003.pdf), diakses 19 Maret 2019.

Universitas Negeri Malang. 2017. Pedoman Penulisan Karya Ilmiah. Malang: Universitas Negeri Malang.

Yusuf, Dani. 2017, Sistem Peminjaman Barang di Perusahaan Menggunakan Teknologi RFID. Jurnal Pelita Bangsa. 6(1), 4958. Dari jurnal.pelitabangsa.ac.id/index.php/sigma/article/view/107/74. 